International Review of Research in Open and Distributed Learning Volume 16, Number 4

October - 2015

\title{
An Investigation of University Student Readiness towards M-learning using Technology Acceptance Model
}

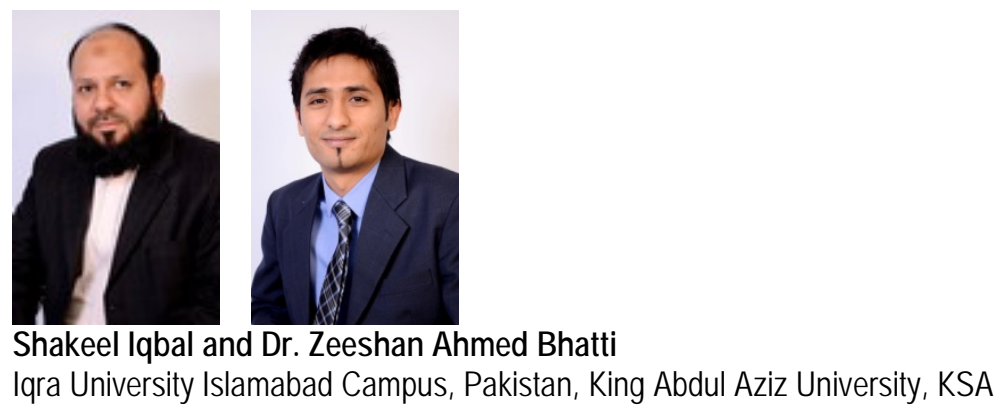

\begin{abstract}
M-learning is learning delivered via mobile devices and mobile technology. The research indicates that this medium of learning has potential to enhance formal as well as informal learning. However, acceptance of m-learning greatly depends upon the personal attitude of students towards this medium; therefore this study focuses only on the individual context in which the role of student's readiness towards m-learning is investigated using Technology Acceptance Model (TAM). TAM is the popular choice among the researchers for investigating acceptance of any new technology primarily because of its robust and parsimonious nature. The sample selected for this study consisted of students from the private sector universities in a developing country. A structured questionnaire was used for data collection. The final results of investigation were based on 244 valid responses. The results indicate that the students' skills and psychological readiness strongly influence their perceived ease of use (PEU) and perceived usefulness (PU) of m-learning, whereas both these constructs positively influenced their behavioral intention to use m-learning. The findings of this study have theoretical as well as practical implications which are discussed at the end.
\end{abstract}


Keywords: M-Learning Adoption, Technology in Higher Education, Technology Acceptance Model

\section{Introduction}

There has been a tremendous growth in research related to mobile-based technologies in the past decade; specifically in the fields of mobile commerce, mobile banking, and mobile learning (Turban, King, Lee, Liang, \& Turban, 2015; Shaikh \& Karjaluoto, 2015; Chung, Chen, \& Kuo, 2015). The reason for this has been advancement in mobile technology and a decrease in its cost. A growing portion of the world population is getting access to mobile devices, specifically tablet PCs and Smartphones. This worldwide enthusiasm towards mobile devices is due to its "handy and compact" nature. According to Gartner (2014), Smartphone sales in 2018 will reach 88\% of global mobile phone sales, compared to $66 \%$ in 2014. Smartphones are increasingly becoming popular among youth. According to Deloitte Global Mobile Consumer Survey 2013, Smartphones penetration among the youth aged 18-24 in the developed countries is 72\% (Deloitte, 2013). Youth in developing countries are rapidly catching the wave, mainly because of the availability of low cost android-based Smartphones in the market.

This increase in ownership of Smartphones among the youth is the main motivating force prompting researchers to come up with ideas of how to use them for teaching and learning, thus developing the field of m-learning. M-learning can be considered a further step in electronic learning (e-learning) in which learning is transmitted via wireless mode and mobile devices such as mobile/Smartphones, laptops, personal digital assistants (PDAs), and tablet PCs (Attewell, 2005). M-learning is emerging as a powerful medium delivering knowledge and changing students' expectations of (anytime and anywhere) learning. Current university students, who mostly belong to generation $\mathrm{Y}$ (and can be called the net-generation), are ideal candidates for $\mathrm{m}$ learning because they were born into an emerging world of technology and have grown up surrounded by smart phones, laptops, tablets, and other gadgets. In times ahead, educational institutions will be forced to meet changing requirements of learners to stay competitive. But before launching any m-learning initiative at university level, students' perception of m-learning should be investigated (Cheon, Lee, Crooks \& Song, 2012).

In higher learning context, successful implementation of m-learning cannot be achieved without active participation of the students. Acceptance of m-learning greatly depends upon personal attitude of students, as Liaw (2007) contended personal attitudes are a major factor to affect individual usage of IT. Therefore, for developing an appropriate m-learning environment it is essential to develop an understanding of students' attitude towards m-learning (Sánchez-Franco, Martínez-López \& Martín-Velicia,, 2009). Individual context is one of the three major factors (individual context, organizational context, and social context) affecting behavioral intention to use IT as defined by Park, Nam and Cha (2012). This study focuses only on the individual context 
to investigate the impact of student readiness on m-learning adoption as students are the end users and teachers and IT personnel represent the suppliers of m-learning (Iqbal \& Qureshi, 2012).

In order to explore the students' readiness towards adoption of m-learning, technology acceptance model (TAM) is used as the base model. Many IS researchers have confirmed the validity of the two main constructs of TAM (i.e., perceived usefulness (PU) and perceived ease of use (PEU)) in predicting the individual's acceptance of different information technologies (e.g., see the studies of Matthieson, 1991; Adams, Nelson \&Todd, 1992; Chin \& Todd, 1995; Martocchio $\&$ Webster, 1992). TAM is one of the most widely used models to investigate adoption of a new technology as it is considered a parsimonious and powerful theory by the IS community (Lucas \& Spitler, 1999; Venkatesh \& Davis, 2000). However, the main weakness of TAM pointed out by researchers is its inability to explain the external variables affecting users' perceived usefulness and perceived ease of use (Legris, Ingham \& Collerette, 2003). These external variables depend largely upon the technology, users, and area of application. Since this study is related to $\mathrm{m}$ learning, the variables affecting PU \& PEU should be selected in this context. We have extended TAM by incorporating student's readiness as the factor affecting PU and PEU of students and their intention to adopt $\mathrm{m}$-learning in the university environment.

Different researchers have studied student readiness with respect to m-learning (e.g., Cheon et al., 2012, Hussin, Manap, Amir \& Krish 2012; Mahat, Ayub \& Luan, 2012), but the concept of student readiness towards m-learning is still evolving. Review of literature on m-learning in higher education indicates an absence of a concise and well-established survey instruments to assess student readiness towards m-learning (Khaddage \& Knezek, 2013). The scale used in this study for measuring students' readiness is an inspiration from Hussin et al. (2012) who used basic readiness, psychological readiness, skills readiness, and budget readiness as the variables measuring student readiness. Since basic readiness and budget readiness is mostly related to smart phone ownership, we have focused mainly on psychological readiness and skills readiness as the factors defining students' readiness.

\section{Literature Review}

Research on m-learning had gained momentum specifically during the past two decades. There are several advantages claimed for m-learning: It has the potential to bridge the digital divide; it promotes independent and collaborative learning, enhances self-confidence and self-esteem of the learner, improves numerical skills, promotes education in informal settings, and engages learners for longer periods (Attewell, 2005). However, it has challenges of its own and several problems are associated with this technology as pointed out by Siau, Lim and Shen (2001): small screen size, short battery life, limited memory, less computational power, smaller keyboard, unfriendly user interface, and graphical limitations. Due to these limitations switching from elearning to m-learning is not as straight forward a task as it seems to be. Some of the learners might not find it convenient as their preferred mode of learning.

This work is licensed under a Creative Commons Attribution 4.0 International License. 


\section{Mobile Learning in Higher Education}

Several researchers conducted their studies on m-learning adoption using TAM. For example, Tan, Ooi, Sim and Phusavat (2012) used subjective norms and individual differences as external variables along with original TAM constructs to explore the adoption of m-learning in Malaysia. TAM was used as a base model by Phuangthong and Malisawan (2005) in a Thailand-based study to explore the factors affecting adoption of m-learning based on third generation (3-G) technology. An m-learning adoption model for university students is proposed by Almasri (2014) extending TAM with two external variables: mobile readiness and perceived interaction. Students' readiness has been used in the studies of Cheon et al. (2012), Hussin et al. (2012) and Mahat et al. (2012) but all of these studies have defined student readiness differently. Hussin et al. (2012) defined student readiness in terms of psychological readiness and skills readiness, but they have not studied how these factors affect students PU \& PEU; the two main constructs of widely-used and validated TAM.

Readiness to use a new technology is the inclination of the users towards a new technology to accomplish job and non-job related tasks. In one of the studies conducted on the topic of elearning readiness Chapnick (2000) pointed out the following eight factors important for elearning adoption: psychological, technical, financial, sociological, human resource, equipment, and content readiness. Since, m-learning evolved from elearning, the same factors can be considered important for m-learning.

A review of literature on the topic of readiness to adopt a new technology, highlight the following characteristics that play a vital role in adoption of a new technology: prior experience, training, personal innovativeness, self-efficacy, preference for a specific mode of learning and affordability in terms of cost (Erlich, Erlich-Philip \& Gal-Ezer, 2005; Dishaw \& Strong, 1999; Agarwal \& Prasad, 1997; Robinson, Marshall \& Stamps, 2005, Schillewaert, Ahearne, Frambach \& Moenaert, 2005).

\section{Research Model and Hypotheses Development Technology Acceptance Model}

Fishbein and Ajzen (1975) proposed theory of reasoned action (TRA) which is considered to be a very useful model to predict and explain the human behavior in variety of domains (Chen, Gillenson \& Sherrell, 2002). Technology Acceptance Model (TAM) proposed by Davis (1989) is considered an extension of TRA. TAM is popular choice among the scholars for investigating acceptance of any new technology primarily because of its robustness and parsimonious nature. Several researchers who studied the phenomenon of m-learning adoption among university students have used TAM as the basis of their investigation (e.g., see Ju, Sriprapaipong \& Minh., 2007; Huang, Lin \& Chuang, 2007; Chang, Yan \& Tseng, 2012). The TAM suggests that attitude towards using a new technology is positively influenced by the beliefs that it is easier to use (perceived ease of use - PEU) and its adoption will result in enhanced productivity (perceived usefulness - PU). PU is "the degree to which a person believes that using a particular system 
would enhance his or her job performance" (Davis, 1989; p.320). Many researchers have found a positive relationship between PU and BI to use a new technology (Chan, 1996). Hence, we formally state that:

H1: PU has a significant positive effect on BI to use m-learning.

PEU is the extent to which a person believes that using a technology will be free of effort (Davis, 1989). Previous studies have confirmed a positive relationship between PEU and BI (Venkatesh, 2000). Different studies conducted on adoption of new technologies such as online banking, ecommerce, m-commerce, and wireless internet have confirmed a positive impact of PEU on BI (Lu \& Zhang, 2003 Lim, Lee, Hur \& Koh, 2009; Lin \& Wang, 2006; Wang \& Barnes, 2007). On similar lines, we propose:

H2: PEU has a significant positive impact on users' BI to use m-learning.

TAM suggests a significant positive relationship between PEU and PU - if any user finds a technology easier to use he will have a positive attitude towards its usefulness. This positive relationship is confirmed by several studies (e.g., Hu, Chau, Sheng \& Tam, 1999; Bruner \& Kumar, 2005), therefore the following hypothesis is proposed:

H3: PEU has a positive impact on PU.

Both attitudes towards usage (AT) and behavioral intention to use (BI) are common to TRA and TAM; however in several TAM-based studies, the direct effect of PU and PEU on BI is also studied. Since PU and PEU are attitudinal scales the direct association between PU/PEU and BI can be determined as done by Subramanian (1994), Szanja (1996) and Venkatesh \& Davis (1996 \& 2000). On the similar lines, direct impact of PU and PEU on BI is observed in this study. BI is the degree of likelihood that a person will adopt a certain technology. Davis (1989) in their TAM suggested that BI would actually lead to actual usage of a certain technology. Several studies on technology adoption confirmed that BI resulted in adoption/ usage of a technology (e.g., see Lucas \& Spitler, 1999; Vijayasarathy, 2004). In this study BI is defined as a university students' intention to adopt m-learning.

\section{Student Readiness}

Personal satisfaction and achievement in online learning environments (OLEs) depends upon different personal qualities as indicated in some of the studies conducted on students' readiness and risk of dropout (Lee, Hong \& Ling, 2001; Muse, 2003). The personal qualities required for adoption of a new technology can be divided into four categories: technical skills, learning preferences, attitude towards technology, and computer self-efficacy (Erlich et al., 2005; Shih, Chen, Chang \& Kao, 2010). Students having required technical skills can better engage themselves in the use of a new technology than those who do not have those skills. As pointed out by Erlich et al. (2005), the students well familiar with the use of computers before registering for an online 
course reported less anxiety and frustration compared to those not familiar with using a computer.

Different students have different learning styles, as well as their preference for the method of learning - some students are more comfortable in the online environment than others (Iqbal, 2013). Similarly, some users show greater inclination towards using new technology if they have the ability and confidence in accomplishing tasks using proposed technology. In computer sciences, this ability of the users is termed as Computer self-efficacy (CSE). Studies have shown high correlation among CSE and PEU (Gong, Xu, \& Yu, 2004). The motivation level of students having higher degree of CSE were found to be comparatively better than those with lower CSE in online learning environments (OLEs) due to higher PU and satisfaction in online study programs. Based on this discussion we propose:

H4: Student Readiness (SR) towards m-learning has a positive impact on perceived usefulness (PU) of m-learning.

H5: Student Readiness (SR) towards m-learning has a positive impact on perceived ease of use (PEU) of m-learning.

\section{Research Model}

Based on the above-mentioned arguments, we propose the following model which is an extension of TAM with student readiness as a new construct effecting PU and PEU:

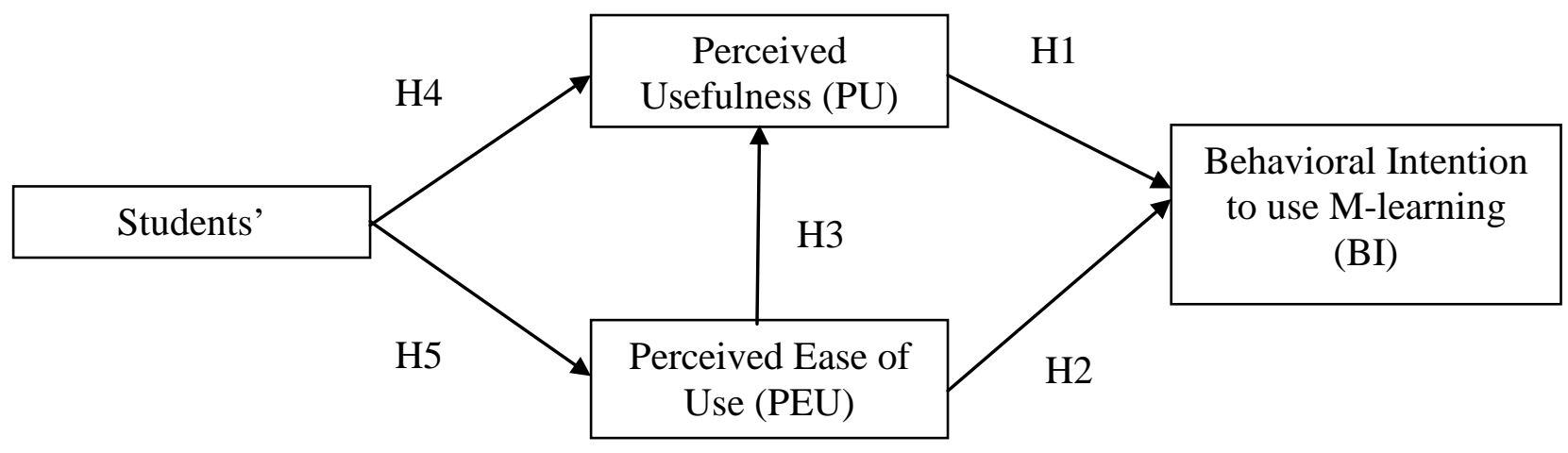

Figure 1. Proposed research model for m-learning adoption among university students. 


\section{Research Methodology}

\section{Participants}

The sample selected for this study consisted of private sector universities operating in Rawalpindi/ Islamabad. The reason for selecting private sector universities is that the students studying in these universities mostly come from upper middle and elite class and are mostly familiar with Smartphone usage and features. Based on Higher Education Commission's (HEC) ranking of private sector universities, three top ranking universities operating in the twin cities were selected for survey. The survey was conducted during J anuary - February, 2015. Majority of the respondents were male (73\%) and $87 \%$ of the respondents fall in the age group 19-25 years. All the respondents belong to Engineering, Arts and Business degree programs. Almost $70 \%$ of the students owned a Smartphone. Table 1 shows the demographic profile of the respondents.

Table 1

Demographic Profile of Respondents

\begin{tabular}{llcc}
\hline Measure & Items & Frequency & Percent \\
\hline Gender & Male & 179 & 73.4 \\
& Female & 65 & 26.6 \\
& Total & 244 & 100 \\
\hline Age & Below 16 years & 0 & 0 \\
& 16-19 years & 32 & 13.1 \\
& 19-22 years & 116 & 47.5 \\
& 22-25 years & 72 & 29.5 \\
& Above 25 years & 24 & 9.8 \\
& Total & 244 & 100 \\
\hline Majors & Engineering & 74 & 30.3 \\
& Arts & 56 & 22.9 \\
& Business & 114 & 46.7 \\
& Total & 244 & 100 \\
\hline Smartphone & & & \\
Ownership & Yes & 170 & 69.7 \\
& No & 74 & 30.3 \\
& Total & 244 & 100 \\
\hline
\end{tabular}

A summary of the responses with respect to current educational usage of Smartphones is shown in Table 2. The most commonly used education related feature was text messaging fellow 
classmates regarding course content (74\%) and social networking (68\%). Reading assignments (64\%) and browsing for course related information (60\%) were also found significantly common. Taking photographs/recording videos for class presentations (54\%), assessing LMS (51\%) and writing notes on mobile device (48\%) were comparatively less frequently used features. The reason for lesser number of students assessing LMS could be that all of the universities in the sample are not offering LMS facilities to the students. Writing notes on mobile phones was found less popular since one of the weaknesses of mobile devices is smaller keyboards which make typing text somewhat cumbersome.

Table 2

Current Education Related Usage of Smartphones

\begin{tabular}{|c|c|c|c|c|}
\hline & \multicolumn{2}{|c|}{ YES } & \multicolumn{2}{|c|}{ NO } \\
\hline & Freq. & Percent & Freq. & Percent \\
\hline $\begin{array}{l}\text { Have you ever read an } \\
\text { assignment or any article on your } \\
\text { smart phone? }\end{array}$ & 155 & 63.7 & 89 & 36.3 \\
\hline $\begin{array}{l}\text { Have you ever taken } \\
\text { picture/video with your smart } \\
\text { phone for an assignment? }\end{array}$ & 132 & 54 & 112 & 46 \\
\hline $\begin{array}{l}\text { Have you ever used your smart } \\
\text { phone to look up for something } \\
\text { that you didn't know or didn't } \\
\text { understand during a class? }\end{array}$ & 146 & 60 & 98 & 40 \\
\hline $\begin{array}{l}\text { Have you ever accessed an } \\
\text { Educational Management system } \\
\text { (e.g., Moodle) on your smart } \\
\text { phone? }\end{array}$ & 125 & 51.2 & 119 & 48.8 \\
\hline $\begin{array}{l}\text { Have you ever written notes on } \\
\text { your smart phone to remind } \\
\text { yourself of an assignment? }\end{array}$ & 117 & 47.9 & 127 & 52.1 \\
\hline $\begin{array}{l}\text { Have you ever engaged in social } \\
\text { networking using your smart } \\
\text { phone? }\end{array}$ & 165 & 67.6 & 79 & 32.4 \\
\hline $\begin{array}{l}\text { Have you ever texted a classmate } \\
\text { about the contents of the class. }\end{array}$ & 180 & 74 & 64 & 26 \\
\hline
\end{tabular}




\section{Data Collection}

A questionnaire was adapted from the previous studies on this topic. The questionnaire consisted of three parts: Part I recorded the demographic information related to age, degree program, education, gender, and smart phone ownership. Part II gathered the information related to current usage of Smartphones for educational purposes. Part III gathered information with respect to the variables discussed above on a seven-point Likert scale. The seven-point Likert scale is preferred over other scales because it offers optimum reliability (Symonds, 1924) and minimizes many neutral responses. The construct of PU, PEU, and BI were adopted from the previous studies of Davis (1989, 1993), Moon and Kim (2001), Bagozzi, Baumgartner \& Yi (1992) and Hu et al. (1999). Student Readiness consisted of 12 items which were adopted from different studies conducted by Hussin et al., 2012; Compeau and Higgins, 1995; Schillewaert et al., 2005; Shih et al., 2010. Once the initial questionnaire was developed it was presented to several experts including university professors and doctoral students to give their opinion and review about the proposed instrument. The basic idea was to ensure the content validity of the instrument. Based on the reviews provided by these experts some of the items were dropped, whereas some needed slight modification in their wording to clarify the meaning to the respondents. After the second round of reviews, a 22 items questionnaire was finalized.

Help was taken from the faculty members of the selected universities in getting the questionnaire filled and were mostly filled in a classroom setting. A brief introduction on m-learning and the purpose of the survey was given to the students filling the questionnaire. Total 300 questionnaires were distributed out of which 256 completely filled questionnaires were considered for further analysis; hence the response rate was 85\%. The responses were screened for any outliers and 12 responses had to be dropped since they were found outliers. 244 responses were considered for final analysis.

\section{Data Analysis}

First of all, an exploratory factor analysis (EFA) on SPSS v.20 was carried out to explore the number of variables to be used in our research model. Principal components extraction with varimax rotation was applied on the proposed constructs. All the proposed constructs loaded on single component except student readiness. The rotated component matrix for student readiness displayed two distinct factors: skills readiness and psychological readiness. One item in students readiness scale was dropped on account of cross-loading.

Confirmatory factor analysis was conducted next using AMOS v.17 to assess the validity and reliability of the data. The proposed model included 21 items describing five latent constructs: skills readiness, psychological readiness, perceived usefulness, perceived ease of use, and behavioral intention to use m-learning. 


\section{Measurement Model}

The measurement model is considered fit for model testing if it is reliable and valid, hence the reliability of measures and their convergent and discriminant validity is verified. For this purpose, Fornell and Larcker (1981) suggested three criteria for verifying convergent validity: the factor loading for individual items is more than 0.50, the average variance extracted (AVE) are above 0.50 and the composite reliability (CR) of all the constructs is above 0.80 . Table 3 shows all these three criteria are met and hence, convergent validity of the measurement model is verified. For confirmation of validity of data Cronbach Alpha is calculated and as shown in Table 3, the Cronbach alpha's value for all the constructs is above 0.90 , well above the minimum acceptable value of 0.60 (Nunnally, 1978).

Table 3

Results of Confirmatory Factor Analysis, Validity Analysis, and Reliability Test

\begin{tabular}{|c|c|c|c|c|c|}
\hline Concept & Items & Estimate & $\begin{array}{l}\text { Average } \\
\text { Variance } \\
\text { Extracted } \\
(>0.50)\end{array}$ & $\begin{array}{l}\text { Composite } \\
\text { Reliability } \\
(>0.80)\end{array}$ & $\begin{array}{l}\text { Cronbach } \\
\text { Alpha } \\
(>0.60)\end{array}$ \\
\hline \multirow{4}{*}{ Skills Readiness } & SKR1 & 0.827 & \multirow{4}{*}{0.742} & \multirow{4}{*}{0.92} & \multirow{4}{*}{0.919} \\
\hline & SKR2 & 0.880 & & & \\
\hline & SKR3 & 0.893 & & & \\
\hline & SKR4 & 0.844 & & & \\
\hline \multirow{4}{*}{ Psychological Readiness } & PR1 & 0.872 & \multirow{4}{*}{0.701} & \multirow{4}{*}{0.903} & \multirow{4}{*}{0.903} \\
\hline & PR2 & 0.861 & & & \\
\hline & PR3 & 0.821 & & & \\
\hline & PR4 & 0.792 & & & \\
\hline \multirow{5}{*}{ Perceived Usefulness } & PU1 & 0.895 & \multirow{5}{*}{0.773} & \multirow{5}{*}{0.944} & \multirow{5}{*}{0.944} \\
\hline & PU2 & 0.892 & & & \\
\hline & PU3 & 0.870 & & & \\
\hline & PU4 & 0.863 & & & \\
\hline & PU5 & 0.877 & & & \\
\hline \multirow{4}{*}{ Perceived Ease of Use } & PEU1 & 0.869 & \multirow{4}{*}{0.758} & \multirow{4}{*}{0.926} & \multirow{4}{*}{0.926} \\
\hline & PEU2 & 0.881 & & & \\
\hline & PEU3 & 0.863 & & & \\
\hline & PEU4 & 0.869 & & & \\
\hline \multirow{4}{*}{ Behavioral Intention } & BI1 & 0.894 & \multirow{4}{*}{0.779} & \multirow{4}{*}{0.934} & \multirow{4}{*}{0.933} \\
\hline & $\mathrm{BI} 2$ & 0.883 & & & \\
\hline & $\mathrm{BI3}$ & 0.876 & & & \\
\hline & $\mathrm{BI} 4$ & 0.877 & & & \\
\hline
\end{tabular}


For assessing discriminant validity of the constructs, Fornell and Larcker's (1981) suggested method of comparing the square root of the average variance extracted (AVE) for a given construct with its corresponding correlation values was conducted. As shown in Table 4, the diagonal values represent the square roots of AVE which are higher compared to the values in their corresponding rows and columns which indicates satisfactory level of discriminant validity.

Table 4

Discriminant Validity for the Measurement Model

\begin{tabular}{llllll}
\hline Construct & SKR & Psy & PU & PEU & BI \\
\hline SKR & $\mathbf{0 . 8 6 1}$ & & & & \\
Psy & 0.295 & $\mathbf{0 . 8 3 7}$ & & & \\
PU & 0.331 & 0.200 & $\mathbf{0 . 8 7 9}$ & & \\
PEU & 0.300 & 0.304 & 0.330 & $\mathbf{0 . 8 7 1}$ & \\
BI & 0.391 & 0.243 & 0.614 & 0.356 & $\mathbf{0 . 8 8 3}$ \\
\hline
\end{tabular}

\section{Results of Structural Modeling Analysis}

\section{Structural model}

Structural Equation modeling was applied next to investigate the relationships among the research variables and the standardized path coefficients for confirmation of the proposed hypotheses. The measurement model test presented a good fit between the data and proposed measurement model as shown in table 5:

Table 5

Model Evaluation and Overall Fit Measurement

\begin{tabular}{lcc}
\hline \multicolumn{1}{c}{ Measure } & $\begin{array}{c}\text { Suggested } \\
\text { Values }\end{array}$ & $\begin{array}{c}\text { Observed } \\
\text { Values }\end{array}$ \\
\hline Root mean square residual (RMR) & $<0.05$ & 0.041 \\
Comparative fit index (CFI) & $>0.9$ & 0.989 \\
Goodness of fit index (GFI) & $>0.9$ & 0.922 \\
Normed fit index (NFI) & $>0.9$ & 0.95 \\
Non-normed fit index & $>0.9$ & 0.987
\end{tabular}




$$
\begin{aligned}
& \begin{array}{l}
\text { Root mean square error of } \begin{array}{c}
<0.05 \text { or } \\
<0.08
\end{array} \\
\text { approximation (RMSEA) }
\end{array} \\
& \hline
\end{aligned}
$$

\section{Hypotheses Testing}

Figure 2 shows the standardized path coefficients and significant structural relationships among the research variables.

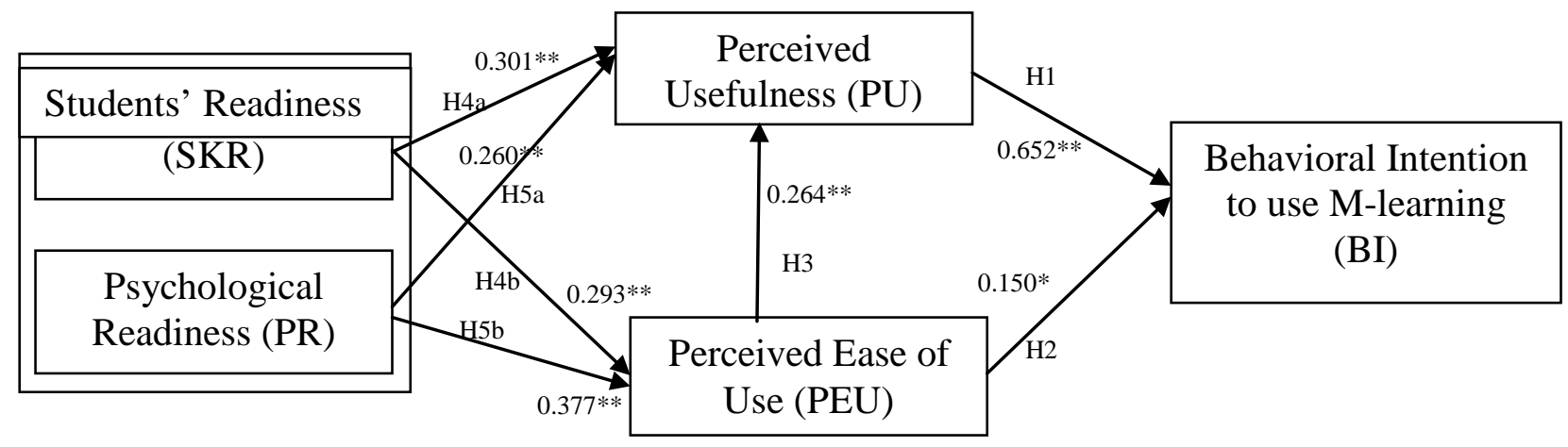

Figure 2. Results of structural modeling analysis (**significant at 0.001 level; *significant at .05 level)

Table 6

Results of Hypotheses Testing

\begin{tabular}{lcccc}
\hline \multicolumn{1}{c}{ Hypotheses } & $\begin{array}{c}\text { Standard } \\
\text { Path } \\
\text { Coefficients } \\
\end{array}$ & T-Values & Significance & Support \\
& $\boldsymbol{\beta}$ & & & \\
\hline H1: PU ---> BI & 0.652 & 14.453 & $\mathrm{p}<0.001$ & Yes \\
H2: PEU ---> BI & 0.15 & 7.791 & $\mathrm{p}<0.05$ & Yes \\
H3: PEU ---> PU & 0.264 & 8.512 & $\mathrm{p}<0.001$ & Yes \\
H4a: SKR ---> PU & 0.301 & 8.327 & $\mathrm{p}<0.001$ & Yes \\
H4b: SKR ---> PEU & 0.293 & 6.559 & $\mathrm{p}<0.001$ & Yes \\
H5a: PR ---> PU & 0.26 & 7.964 & $\mathrm{p}<0.001$ & Yes \\
H5b: PR ---> PEU & 0.377 & 7.532 & $\mathrm{p}<0.001$ & Yes \\
\hline
\end{tabular}


$\mathrm{PU}=$ perceived usefulness; $\mathrm{BI}$ = behavioral intention to use; $\mathrm{PEU}=$ perceived ease of use; $\mathrm{SKR}=$ skills readiness; $\mathrm{PR}=$ psychological readiness

PU has a significant positive impact on $\mathrm{BI}$ to use M-learning $\left(\beta=0.65^{2}\right)$, hence hypothesis $\mathrm{H} 1$ is accepted. The impact of PEU on BI to use M-learning was found significant at $\mathrm{p}<.05(\beta=0.150)$, hence $\mathrm{H} 2$ was accepted. A significant positive impact of PEU is observed on PU ( $\beta=0.264)$ due to which hypothesis H3 is accepted. Skills readiness has a significant positive impact on both PU ( $\beta=0.301)$ \& PEU $(\beta=0.293)$, hence hypothesis $4 \mathrm{a}$ and $4 \mathrm{~b}$ are accepted. The impact of psychological readiness on (PU $\beta=0.260)$ and PEU $(\beta=0.377)$ was also found significant, hence hypotheses $5 \mathrm{a} \& 5 \mathrm{~b}$ are also accepted.

\section{Discussion of the Results}

The objective of this study was to investigate the factors affecting the adoption of m-learning among university students and to find out the relationship among those factors. An extension of TAM was used with students' readiness as the only external variable in this study. The results indicate that students' intention to adopt m-learning is positively affected by their perceived usefulness. Similar findings were reported by Davis (1989 \& 1983), Subramanian (1994) and Taylor \& Todd (1995a, 1995b). This finding indicates that the adoption of a new system mainly depends upon the perception that this system will result in enhanced performance. Recent developments in telecommunication infrastructure in Pakistan (the government issued 3G \& 4G licenses in 2014) have opened new door of opportunities for using Smartphones in novel productive ways. This development will further enhance the public perception regarding usefulness of Smartphones.

Learners' PEU has significant positive effects on their intention to use m-learning. This finding is similar to the findings of Venkatesh (2000), Venkatesh \& Davis (1996) and Wu \& Wang (2005). The increased ownership of Smartphones among students in Pakistani universities is primarily due to the availability of low cost android-based Smartphones in the markets. Because of this increased ownership of Smartphones, students are quite familiar with Smartphone features used in $\mathrm{m}$-learning. Therefore, $\mathrm{PEU}$ is a factor encouraging them to adopt $\mathrm{m}$-learning.

We also found a significant positive impact of PEU on PU of m-learning. There is strong association between these two constructs as confirmed by other studies conducted on adoption of technology (Davis et al., 1989; Taylor \& Todd, 1995; Agarwal \& Prasad, 1997). The implications of this finding is that an otherwise productive IS might not catch the attention of end users if it is not easy to use. A strong association between PEU and PU is well established in technology adoption literature.

The results also confirmed a strong effect of skills readiness on both PU \& PEU. Generally speaking, if the users possess the skills required for using a new system, it will enhance their perception regarding usefulness and ease of use of that system. Therefore, end users' training can 
lead to increased system acceptability. In case of m-learning, the students own and are already familiar with different m-learning related features of Smartphones, they possess the skills required for m-learning adoption which creates positive perception regarding usefulness and ease of use of m-learning. Smartphones are just like mobile computers carried by users in their pockets offering them access to learning material anywhere and anytime, thus resulting in an overall increase in users' productivity (PU) and convenience (PEU).

A positive significant impact of psychological readiness on both PU and PEU is also confirmed from the results of this study. This implies that if the end users of an IS are optimistic regarding its future diffusion, the chances of its acceptability and adoption are increased. The social learning theory proposed by Bandura (1969) suggests that people can learn by observing others and when majority of the people ( $70 \%$ in this study) are using Smartphones, it is certainly going to affect the behavior of others resulting in positive perceptions with respect to PU and PEU of m-learning.

\section{Limitations and Directions for Future Research}

The study is limited in terms of sample size and sample selection. The respondents from only three universities were selected using non-random sampling technique. The second limitation of this study is that we have considered only one factor relating to students (i.e., students' readiness to adopt m-learning) affecting their perceived usefulness and perceived ease of use, whereas practically, there can be several other factors which can effect students perception such as social influence, facilitating conditions and faculty support. It is recommended to increase the sample size in future studies and employ random sampling technique to avoid sampling biasness. It is

also recommended to include other factors (as mentioned above) to enhance the predicting capability of the proposed model.

\section{References}

Adams, D.A., Nelson, R.R., Todd, P.A. (1992). Perceived usefulness, ease of use, and usage of information technology: A replication, MIS Quarterly, 16(2), pp.227-47.

Agarwal, R., Prasad, J . (1997). The role of innovation characteristics and perceived voluntariness in the acceptance of information technologies, Decision Sciences, 28(3), pp.557-82.

Almasri, A.K.M. (2014, J uly-August). The influence on mobile learning based on technology acceptance model (TAM), mobile readiness (MR) and perceived interaction for higher education students, International J ournal of Technical Research and Application, 2(1), 05-11. 
Attewell, J . (2005, October 25-28). From research and development to mobile learning: Tools for education and training providers and their learners. Paper presented at the $4^{\text {th }}$ World Conference on m-learning Cape Town, South Africa. Retrieved April 2015 from http:// www.mlearn.org.za/CD/papers/Attewell.pdf

Bagozzi, R. P., Baumgartner, H., \&Yi, Y. (1992). State versus action orientation and the theory of reasoned action: An application to coupon usage. J ournal of Consumer Research, 18(4), 505-518.

Bandura, A. (1969) Social-learning theory of identificatory processes. Goslin DA, ed. Handbook of Socialization Theory and Research, Chicago: Rand McNally.

Bruner, G. C., \& Kumar, A. (2005). Explaining consumer acceptance of handheld internet devices. J ournal of Business Research, 58(5), 553-558.

Chang, C. C., Yan, C. F., \&Tseng, J . S. (2012). Perceived convenience in an extended technology acceptance model: Mobile technology and English learning for college students. Australasian J ournal of Educational Technology, 28(5), 809-826.

Chapnick, S. (2000). Are you ready for e-learning? Learning circuits: ASTD’s Online Magazine All About E- Learning. Retrieved J uly 2015 from http:// www.learningcircuits.org/2000/nov2000/Chapnick.htm

Chen, L., Gillenson, M. L., \& Sherrell, D. L. (2002). Enticing online consumers: An extended technology acceptance perspective. Information \& management, 39(8), 705-719.

Cheon, J ., Lee, S., Crooks, S. M., \& Song, J . (2012). An investigation of mobile learning readiness in higher education based on the theory of planned behavior. Computers \& Education, 59(3), 1054-1064.

Chin, W. W., \&Todd, P. A. (1995). On the use, usefulness, and ease of use of structural equation modeling in MIS research: A Note of caution. MIS Quarterly, 19(2), 237-246.

Compeau D .R. \&Higgins C. A. (1995). Computer self-efficacy: Development of a measure and initial test, MIS Quarterly, 19(2), 189-211.

Chung, H. H., Chen, S. C., \& Kuo, M. H. (2015). A study of EFL college students' acceptance of mobile learning. Procedia-Social and Behavioral Sciences, 176, 333-339.

Davis, F.D. (1989). Perceived usefulness, perceived ease of use, and user acceptance of information technology. MIS Quarterly, 13(3), 318-39. 
Davis, F.D. (1993). User acceptance of information technology: System characteristics, user perceptions and behavioral impacts, International J ournal of Man-Machine Studies, 38, 475-87.

Deloitte (2013). The state of global mobile consumers: Divergence deepens. Retrieved J anuary, 2015 from http:// www2.deloitte.com/ content/ dam/Deloitte/ global/ Documents/TechnologyMedia-Telecommunications/dttl_TMT-GMCS_January\%202014.pdf

Dishaw, M. T., \& Strong, D. M. (1999). Extending the technology acceptance model with tasktechnology fit constructs. Information \&Management, 36(1), 9-21.

Erlich, Z., Erlich-Philip, I., \&Gal-Ezer, J . (2005). Skills required for participating in CMC courses: An empirical study. Computers \&Education, 44(4), 477-487.

Fishbein, M., Ajzen, I. (1975). Belief, attitude, intention and behavior: An introduction to theory and research. Reading, MA: Addison-Wesley.

Fornell, C., \& Larcker, D. F. (1981). Evaluating structural equation models with unobservable variables and measurement error. J ournal of Marketing Research, 18(1), 39-50.

Gartner (2014). Gartner says worldwide traditional PC, tablet, ultra mobileand mobile phone shipments to grow 4.2 percent in 2014. Retrieved J anuary, 2015 from: http:/ / www.gartner.com/ newsroom/id/2791017

Gong, M., Xu, Y., \&Yu, Y. (2004). An enhanced technology acceptance model for web-based learning. J ournal of Information Systems Education, 15(4), 365-374.

Hu, P. J., Chau, P. Y., Sheng, O. R. L., \& Tam, K. Y. (1999). Examining the technology acceptance model using physician acceptance of telemedicine technology. J ournal of Management Information Systems, 91-112.

Huang, J . H., Lin, Y. R., \& Chuang, S. T. (2007). Elucidating user behavior of mobile learning: A perspective of the extended technology acceptance model. The Electronic Library, 25(5), 585-598.

Hussin, S., Manap, M. R., Amir, Z., \& Krish, P. (2012). Mobile learning readiness among Malaysian students at higher learning institutes. Asian Social Science, 8(12), 276-283.

Iqbal, S. (2013). Impact of Learning Styles on e-Learning Environment: An Empirical Study, International J ournal of Research in Computer Application and Management, 3(5), 6468. Retrieved September 2015 from http:// works.bepress.com/shakeel_iqbal/2 
Iqbal, S., \&Qureshi, I. A. (2012). M-learning adoption: A perspective from a developing country. The International Review of Research in Open and Distributed Learning, 13(3), 147-164.

Ju, T.L., Sriprapaipong, W. and Minh, D.N. (2007), On the success factors of mobile learning. Paper presented at 5th International Conference on ICT and Higher Education, Bangkok. Retrieved March 2014 from http:// www.mendeley.com/catalog/success-factors-mobilelearning/

Khaddage, F., \& Knezek, G. (2013, J anuary). Introducing a mobile learning attitude scale for higher education. In WCCE 2013: Learning while we are connected: Proceedings of the IFIP Computers in Education 2013 World Conference. Nicolaus Copernicus University Press, Torun, Italy, 226-235.

Lee, J ., Hong, N. L., \& Ling, N. L. (2001). An analysis of students' preparation for the virtual learning environment. The Internet and Higher Education, 4(3), 231-242.

Legris, P, Ingham, J \& Collerette, P (2003), Why do people use information technology? A critical review of the technology acceptance model, Information \& Management, 40(3), pp.191204.

Liaw, S. S., Huang, H. M., \& Chen, G. D. (2007). Surveying instructor and learner attitudes toward e-learning. Computers \&Education, 49(4), 1066-1080.

Lim, S. H., Lee, S., Hur, Y., \& Koh, C. E. (2009). Role of trust in adoption of online auto insurance. J ournal of Computer Information Systems, 50(2), 151-159.

Lin, H. H., \& Wang, Y. S. (2006). An examination of the determinants of customer loyalty in mobile commerce contexts. Information \& management, 43(3), 271-282.

Lu, J ., \& Zhang, G. (2003). Cost benefit factor analysis in e-services. International J ournal of Service Industry Management, 14(5), 570-595.

Lucas, H. C., \& Spitler, V. K. (1999). Technology use and performance: A field study of broker workstations. Decision sciences, 30(2), 291-311.

Mahat, J ., Ayub, A. F. M., \&Luan, S. (2012). An assessment of students' mobile self-efficacy, readiness and personal innovativeness towards mobile learning in higher education in Malaysia. Procedia-Social and Behavioral Sciences, 64, 284-290.

Martocchio, J . J ., \& Webster, J . (1992). Effects of feedback and cognitive playfulness on performance in microcomputer software training. Personnel Psychology, 45(3), 553-578. 
Mathieson, K. (1991), Predicting user intentions: Comparing the technology acceptance model with the theory of planned behavior, Information Systems Research, 2(3), pp.173-91.

Mobile phone internet user penetration worldwide (2014, December 29). Retrieved from: http:// www.statista.com/statistics/284202/mobile-phone-internet-user-penetrationworldwide/

Moon, J . W., \& Kim, Y.G. (2001). Extending the TAM for a World-Wide-Web context. Information \& Management, 38(4), 217-230.

Muse, H. E. (2003). The Web-based community college student: An examination of factors that lead to success and risk. The Internet and Higher Education, 6(3), 241-261.

Nunnally, J . (1978). Psychometric theory. New York: McGraw-Hill.

Park, S. Y., Nam, M. W., \& Cha, S. B. (2012). University students' behavioral intention to use mobile learning: Evaluating the technology acceptance model. British J ournal of Educational Technology, 43(4), 592-605.

Phuangthong, D. and Malisawan, S.A. (2005). Study of behavioral intention for 3G mobile technology: Preliminary research on mobilelearning. Paper presented at the 2nd International Conference on eLearning for Knowledge-Based Society, Bangkok.

Pikkarainen, T., Pikkarainen, K., Karjaluoto, H., \& Pahnila, S. (2004). Consumer acceptance of online banking: An extension of the technology acceptance model. Internet research, 14(3), 224-235.

Robinson Jr, L., Marshall, G. W., \& Stamps, M. B. (2005). Sales force use of technology: Antecedents to technology acceptance. J ournal of Business Research, 58(12), 1623-1631.

Sánchez-Franco, M. J ., Martínez-López, F. J ., \& Martín-Velicia, F. A. (2009). Exploring the impact of individualism and uncertainty avoidance in web-based electronic learning: An empirical analysis in European higher education. Computers \& Education, 52(3), 588598.

Schillewaert, N., Ahearne, M. J., Frambach, R. T., \&Moenaert, R. K. (2005). The adoption of information technology in the sales force. Industrial Marketing Management, 34(4), 323-336.

Shaikh, A. A., \& Karjaluoto, H. (2015). Mobile banking adoption: A literature review. Telematics and Informatics, 32(1), 129-142. 
Shih, K., Chen, H., Chang, C., \& Kao, T. (2010). The development and implementation of scaffolding-based self-regulated learning system for e/ m-learning, J ournal of Educational Technology \& Society, 13(1), 80-93.

Siau, K., Lim, E. P., \& Shen, Z. (2001). Mobile commerce: Promises, challenges and research agenda. J ournal of Database Management (J DM), 12(3), 4-13.

Subramanian, G. H. (1994). A replication of perceived usefulness and perceived ease of use measurement. Decision Sciences, 25(56), 863-874.

Symonds, P. M. (1924) On the loss of reliability in ratings due to coarseness of the scale. J ournal of Experimental Psychology, 7, 456-461.

Szajna, B. (1996). Empirical evaluation of the revised technology acceptance model. Management Science, 42, 85-92.

Tan, W.H., Ooi, K.B., Sim, J.J ., \& Phusavat, K. (2012). Determinants of mobile learning adoption: An empirical analysis. J ournal of Computer Information Systems, 52(3).

Taylor, S., \&Todd, P. A. (1995a). Understanding information technology usage: A test of competing models. Information systems research, 6(2), 144-176.

Taylor, S., \& Todd, P. (1995b). Assessing IT usage: The role of prior experience. MIS quarterly, 19(4), 561-570.

Turban, E., King, D., Lee, J . K., Liang, T. P., \&Turban, D. C. (2015). Mobile commerce and ubiquitous computing. In Electronic Commerce. Springer International Publishing Switzerland, 257-308.

Venkatesh, V. (2000). Determinants of perceived ease of use: Integrating control, intrinsic motivation, and emotion into the technology acceptance model. Information systems research, 11(4), 342-365.

Venkatesh, V., \& Davis, F. D. (1996). A model of the antecedents of perceived ease of use: Development and test. Decision sciences, 27(3), 451-481.

Venkatesh, V., \& Davis, F. D. (2000). A theoretical extension of the technology acceptance model: Four longitudinal field studies. Management science, 46(2), 186-204.

Vijayasarathy, L. R. (2004). Predicting consumer intentions to use on-line shopping: The case for an augmented technology acceptance model. Information \& Management, 41(6), 747762. 
Wang, S., \& Barnes, S. (2007, J uly). Exploring the acceptance of mobile auctions in China. Proceedings of the Sixth International Conference on the Management of Mobile Business 9-11J uly, Toronto, Canada, 203-210.

Wu, J . H., \&Wang, S. C. (2005). What drives mobile commerce? An empirical evaluation of the revised technology acceptance model. Information \& management, 42(5), 719-729.

\section{Appendix A}

\section{Definitions of the Variables}

\begin{tabular}{|c|c|c|}
\hline Construct & Definition & Source \\
\hline Students' Readiness & $\begin{array}{l}\text { Student readiness in this study } \\
\text { is defined as a composition of } \\
\text { self-efficacy, training, } \\
\text { affordability in terms of cost, } \\
\text { preference for a specific mode } \\
\text { of learning and personal } \\
\text { innovativeness }\end{array}$ & $\begin{array}{l}\text { Compeau and Higgins, 1995; } \\
\text { Schillewaert et al., 2005; Shih } \\
\text { et al., } 2010\end{array}$ \\
\hline Perceived Usefulness & $\begin{array}{l}\text { The degree to which a person } \\
\text { believes that using m-learning } \\
\text { would enhance his/her job } \\
\text { performance. }\end{array}$ & Davis, 1989 \\
\hline Perceive Ease of Use & $\begin{array}{l}\text { The degree to which a person } \\
\text { believes that using m-learning } \\
\text { would be free of effort. }\end{array}$ & Davis, 1989 \\
\hline Behavioral Intentions & $\begin{array}{l}\text { The students' likelihood to } \\
\text { engage in m-learning. }\end{array}$ & Davis, 1989 \\
\hline
\end{tabular}

(C) Iqbal and Bhatti 
An Investigation of University Students' Readiness towards M-learning using Technology Acceptance Model Iqbal and Bhatti

\section{Athabasca University $\mathbf{I}$}

(c) 